\title{
A functional Ets DNA-binding domain is required to maintain multipotency of hematopoietic progenitors transformed by Myb-Ets
}

\author{
Norbert Kraut, Jon Frampton, Kelly M. McNagny, and Thomas Graf \\ Differentiation Programme, European Molecular Biology Laboratory, 69012 Heidelberg, Germany
}

\begin{abstract}
Earlier work demonstrated that the Myb-Ets fusion protein of E26 avian leukemia virus induces the proliferation of multipotent hematopoietic progenitors (MEPs). These progenitors differentiate spontaneously at low frequencies along the erythroid lineage, and following the introduction of kinase/ras-type oncogenes or treatment with TPA, they are induced to differentiate along the myelomonocytic and eosinophilic lineages. Here, we show that the ts1.1 mutant of E26 encodes an Ets DNA-binding domain that is both defective and thermolabile for binding of specific DNA sequences. Correlating with this, ts1.1 MEP colonies transformed at the permissive temperature exhibit elevated levels of erythroid cells and eosinophils, whereas at the nonpermissive temperature they are induced to differentiate along the erythroid and myelomonocytic lineages and, to a lesser extent, along the eosinophil lineage. Induction of the former two lineages cannot be separated by pulse shift experiments and is essentially completed 2.5 days after temperature shift. Our results indicate that the Ets portion of the Myb-Ets fusion protein inhibits the lineage commitment of multipotent hematopoietic progenitors, probably via binding to regulatory DNA sequences of specific target genes.
\end{abstract}

[Key Words: Retrovirus E26; acute avian leukemia virus; hematopoietic stem cells; lineage commitment]

Received September 6, 1993; revised version accepted November 4, 1993.

In higher vertebrates, eight distinct lineages of blood cells originate from a self-renewing population of pluripotent hematopoietic stem cells (for review, see Metcalf 1989|. Between these pluripotent cells and their monopotent progeny lie ill-defined intermediates capable of giving rise to a subset of the various hematopoietic lineages. Such bi- or tripotent progenitors can offer a simple model for examining decision processes in differentiation. It is believed that a combination of lineage-restricted and ubiquitous transcription factors establish programs of gene expression that are responsible for the phenotype of cells from different lineages.

Analysis of the mechanisms of lineage commitment have been hampered by the fact that normal multipotent progenitors cannot be expanded in culture. Although mouse multipotent hematopoietic cell lines (Greenberger et al. 1983; Spooncer et al. 1984) have been used successfully to address specific questions, we have chosen to use primary chick hematopoietic cells transformed by the E26 acute leukemia virus. In young chicks this virus causes a mixed leukemia, with most cells resembling erythroblasts [which are now believed to consist predominantly of multipotent progenitors /Graf et al. 1992/] and of myeloblasts. When used to infect bone marrow or blastoderm-derived cells in vitro, the virus induces the formation of transformed multipotent colo- nies as well as myeloblast and mixed colonies /Sotirov 1981; Radke et al. 1982; Moscovici et al. 1983; Metz and Graf 1991a; Graf et al. 1992).

E26 expresses its two oncogenes $\mathrm{v}-\mathrm{myb}$ and $\mathrm{v}$-ets as a 135-kD Gag-Myb-Ets fusion protein, termed Myb-Ets for simplicity (Leprince et al. 1983; Nunn et al. 1983). The proto-oncogene forms of $\mathrm{v}-\mathrm{my} b$ and $\mathrm{v}$-ets encode sequence-specific transcriptional activators with distinct DNA-binding specificities (for recent reviews on Myb, see Lüscher and Eisenman 1990; Graf 1992; and on Ets, see Karim et al. 1990; Macleod et al. 1992). Only the fused version of Myb-Ets causes leukemia and is capable of transforming multipotent progenitor cells (MEPs) (Metz and Graf 1991a,b; Graf et al. 1992). These cells are almost completely blocked in their differentiation, typically exhibiting low levels of spontaneous erythroid differentiation. Superinfection of MEPs with retroviruses expressing kinase-type or Ras oncogenes, or treatment of the cells with the phorbol ester TPA, induces a phenotypic change toward cells of the myelomonocytic and eosinophilic lineages (Graf et al. 1992). The mechanisms and respective contributions of $\mathrm{v}-\mathrm{my} b$ and $\mathrm{v}-e$ ts in the induction of proliferation and blocked differentiation of MEPs are still obscure.

To gain insight into the role of the fusion protein in these mechanisms we have used a temperature-sensitive 
mutant of E26 (ts1.1, Golay et al. 1988). This mutant contains a histidine-to-aspartic acid substitution in the DNA-binding domain of Ets (Golay et al. 1988), also called the ETS domain (Karim et al. 1990; Macleod et al. 1992). ts 1.1 was isolated based on the observation that erythroid colonies transformed by the mutant can be induced to mature into erythrocyte-like cells within 4 days after shift to $42^{\circ} \mathrm{C}$. Myeloid cells transformed by $t s 1.1$ resemble promyelocytes (precursors of granulocytes) rather than myeloblasts and cannot be induced to differentiate further by temperature shifts (Golay et al. 1988). We have attributed the change in transforming specificity within the myelomonocytic lineage to an indirect effect of Ets on Myb (Golay et al. 1988; Introna et al. 1990).

Here, we show that the $t s 1.1$ mutation renders the ETS domain of the Myb-Ets fusion protein temperature sensitive for specific DNA binding. We also show that $t s 1.1$ transformed "erythroid" cells are multipotent and that differentiation into erythrocytes and promyelocytes, and to a lesser extent into eosinophils, can be induced by a shift to the nonpermissive temperature, in close correlation to the thermosensitivity of Ets DNA binding. Our studies therefore indicate that the Ets domain is involved in the regulation of genes necessary to maintain the multipotency of E26-transformed hematopoietic progenitors.

\section{Results}

ts1.1-Ets protein is defective and temperature sensitive for DNA binding

Since the initial description of the ts 1.1 E26 as a mutant with a lesion in ets, it was discovered that c-ets-1, the corresponding proto-oncogene, encodes a specific transcription factor (Wasylyk et al. 1990). We therefore decided to examine the DNA-binding properties of the Ets oncoprotein encoded by the mutant virus. For this we studied the carboxy-terminal portion, consisting essentially of the tsl.1-ETS domain, in comparison with the corresponding domains of wild-type E26-Ets and c-Ets$1^{\mathrm{p} 68}$ (hereafter c-Ets). Ets proteins were synthesized in reticulocyte lysates and tested by mobility retardation assays at either room temperature $\left(22^{\circ} \mathrm{C}\right)$ or $42^{\circ} \mathrm{C}$ using a labeled oligonucleotide containing the polyoma enhancer PEA3 element, shown previously to bind c- and $\mathrm{v}$-Ets proteins and to mediate transcriptional activation (Wasylyk et al. 1990; Lim et al. 1992). As shown in Figure $1 \mathrm{~A}, t s 1.1-$ Ets exhibited considerable binding at $22^{\circ} \mathrm{C}$ but no detectable binding at $42^{\circ} \mathrm{C}$. In contrast, binding of c-Ets (Fig. 1A) or v-Ets (not shown) to the PEA3 oligonucleotide was unaffected by the temperature of the binding reactions. Determination of relative binding affinities of the three proteins at $22^{\circ} \mathrm{C}$ by Scatchard analysis showed that the DNA-binding domain of $t s 1$.1-Ets has an affinity $\sim 6$-fold lower than $v$-Ets and $\sim 16$-fold lower than C-Ets (Fig. 1B). Binding of ts1.1-Ets to other Ets target sequences was also found to be defective and thermosensitive (data not shown).

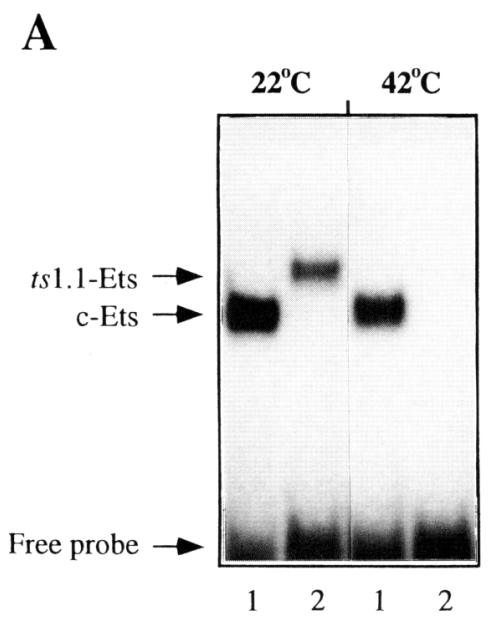

\section{B}

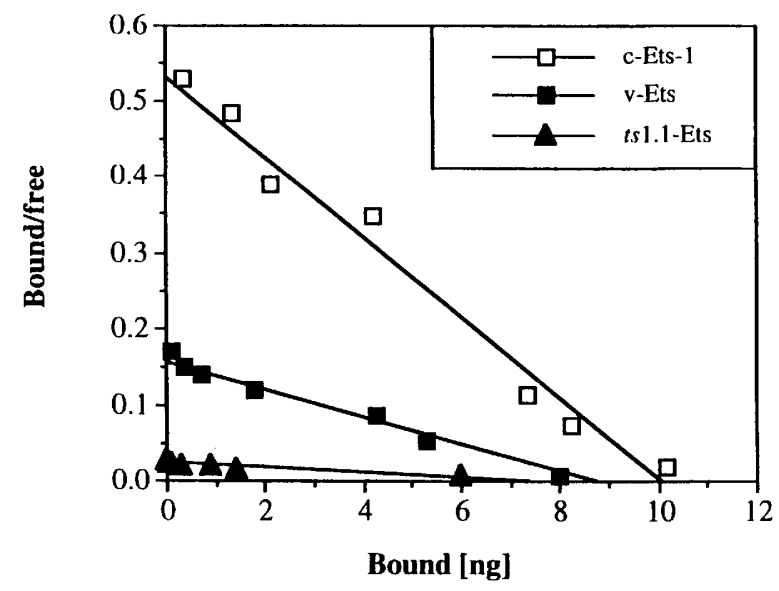

Figure 1. DNA-binding capacity of $t s 1.1-$ Ets at $22^{\circ} \mathrm{C}$ and $42^{\circ} \mathrm{C}$. (A)In vitro-transcribed and -translated $t$ s 1.1-Ets ${ }^{\mathrm{N} \Delta 4}$ (lanes 1 ) and c-Ets ${ }^{\mathrm{N} \Delta 4}$ (lanes 2) were used for binding reaction with ${ }^{32} \mathrm{P}-\mathrm{la}$ beled PEA3 oligonucleotide. Five times the amount of $t s 1.1$ product was used compared with c-Ets, as determined by SDSPAGE (not shown). Binding reactions were carried out at either $22^{\circ} \mathrm{C}$ or $42^{\circ} \mathrm{C}$ while gel electrophoresis was performed at $22^{\circ} \mathrm{C}$. The retarded protein-DNA complexes are indicated by arrows. c-Ets ${ }^{\mathrm{N} \Delta 4}$ migrates faster than $t s 1.1-\mathrm{Ets}^{\mathrm{N} \Delta 4}$, because of the slightly shorter size of the protein (see Lim et al. 1992). (B) Scatchard analysis of a titration experiment in which c-Ets, v-Ets, and ts1.1-Ets DNA-binding domains (N $\Delta 4$ ) were incubated with increasing amounts of PEA3 probe and assayed by mobility retardation. Assuming a 1:1 stoichiometry of protein to DNA in the bound fraction, the intercept at the abscissa indicates the amount of protein capable of binding to DNA. The relative affinity constants of the proteins used for the PEA3 probe are given by the slope of the lines.

The decreased DNA-binding activity of $t s 1.1-$ Ets protein might be explained by a reduction in its stability. We therefore compared the relative in vivo stability of the ts 1.1 and the wild-type E26 fusion proteins in cells grown at either $35^{\circ} \mathrm{C}$ or $42^{\circ} \mathrm{C}$ using a pulse-chase protocol with ${ }^{35} \mathrm{~S}$-labeled proteins. The experiment in Figure 
2A shows that the half-life of the $t s 1.1$ fusion protein at $35^{\circ} \mathrm{C}$ is $\sim 1 \mathrm{hr}$. This is significantly higher than the value observed for the wild-type fusion protein $(<30 \mathrm{~min})$. A temperature shift to $42^{\circ} \mathrm{C}$ did not change the stability of both $t s 1.1$ and wild-type proteins. This suggests that the inactivation of the tsl.1-Ets protein's capacity to bind to Ets-binding sites at $42^{\circ} \mathrm{C}$ results from a conformational change rather than from an increased degradation of the protein.

This idea is also supported by experiments showing that the inactivation of $t s 1.1-\mathrm{v}$-Ets at $42^{\circ}$ can be reversed. For this, binding reactions were back-shifted to $22^{\circ} \mathrm{C}$ for various lengths of time under conditions that do not permit new protein synthesis. The ability of the protein to bind to DNA was then measured by gel retardation assays as described above. As shown in Figure 2B, ts 1.1-Ets regained its ability to bind to DNA within $4 \mathrm{hr}$. In contrast, the binding of c-Ets to the PEA3 oligonucleotide was not significantly affected by the temperatureshift protocol used.

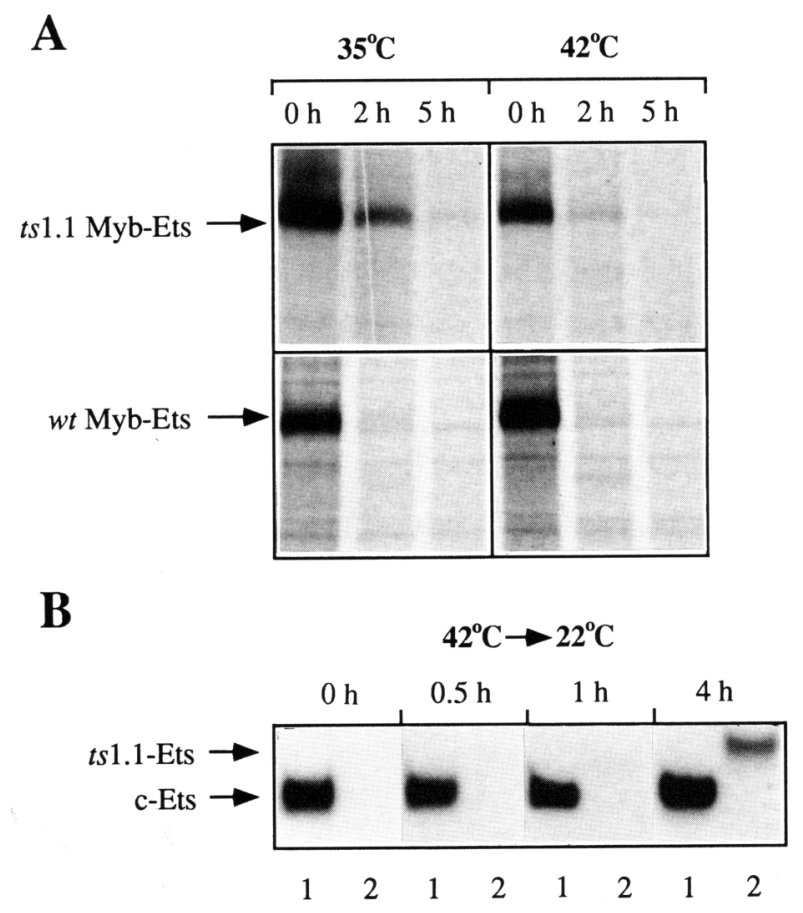

Figure 2. Stability of $t s 1.1 \mathrm{Myb}-$ Ets protein and reactivation of ts1.1-Ets DNA-binding activity. $(A)$ The half-life of $t s 1.1 \mathrm{Myb}$ Ets and wild-type Myb-Ets fusion proteins was determined by pulse-chase experiments in cells maintained at $35^{\circ} \mathrm{C}$ or grown at $42^{\circ} \mathrm{C}$ for $24 \mathrm{hr}$. Cells were labeled with $\left[{ }^{35} \mathrm{~S} /\right.$ methionine for $1 \mathrm{hr}$ (h) and chased for the times indicated. Lysates were then prepared and immunoprecipitated with Myb-specific antiserum. $(B)$ Binding reactions with c-Ets ${ }^{\mathrm{N} \Delta 4}$ (lanes 1) and $t s 1.1-\mathrm{Ets}^{\mathrm{N} \Delta 4}$ (lanes 2) were performed at $42^{\circ} \mathrm{C}$ for $20 \mathrm{~min}$ as in Fig. 1A. The samples were then shifted to $22^{\circ} \mathrm{C}$ for the indicated time periods and subjected to electrophoresis at room temperature. Five times the amount of $t s 1.1-\mathrm{Ets}^{\mathrm{N} \Delta 4}$ translation product was loaded in each case compared with c-Ets ${ }^{\mathrm{N} \Delta 4}$. Note that control lanes 1 and $2\left(22^{\circ} \mathrm{C} / 0 \mathrm{~h}\right)$ are identical with lanes 1 and $2\left(42^{\circ} \mathrm{C}\right)$ in Fig. 1A.
Temperature-induced erythroid differentiation of ts1.1-transformed progenitors is incomplete and transitory

As reported previously (Golay et al. 1988), three types of transformed colonies could be observed after infection of blastoderm cultures; erythroid, myeloid, and mixed. Because we recently discovered that erythroid colonies transformed by wild-type E26 correspond to multipotent progenitors (MEPs, Graf et al. 1992), we decided to reexamine the properties of the corresponding colonies obtained with $t s 1.1$ at $35^{\circ} \mathrm{C}$. In the analysis of 96 individual colonies, each colony was found to express an average of $20 \%$ hemoglobin-positive cells (range $1-60 \%$ ), as detected by staining with benzidine. All of these colonies could be induced to differentiate within 3-4 days into erythrocyte-like cells after a temperature shift to $42^{\circ} \mathrm{C}$, with 2- to 50-fold relative increases in the proportion of hemoglobin-positive cells, depending on the clone tested. Addition of anemic serum, enriched in erythropoietin, substantially increased their growth at $35^{\circ} \mathrm{C}$ and their survival following shift to $42^{\circ} \mathrm{C}$ (N. Kraut and T. Graf, unpubl.). The observed induction of erythroid maturation was also reflected by the up-regulation of erythroid-specific genes. As shown in Figure 3A, using a clone with a low level of hemoglobin expression at $35^{\circ} \mathrm{C}$, up-regulation of $\alpha$-globin, $\beta$-globin, and band 3 mRNAs occurred within $2-8 \mathrm{hr}$ after shift to $42^{\circ} \mathrm{C}$. This shows that the cells rapidly accumulate erythroid-specific gene products and that temperature-induced erythroid differentiation occurs in a coordinated manner, similar to that described for temperature-sensitive sea transformed erythroblasts (Knight et al. 1988).

As also reported earlier (Golay et al. 1988), we noted that in cells shifted for 4 days to $42^{\circ} \mathrm{C}$, maturation along the erythroid lineage was never complete laverage of $76 \%$ benzidine-positive cells, range $40-95 \%$ in 96 clones tested). Therefore, we examined the long-term fate of $t s 1.1$-transformed progenitors shifted to $42^{\circ} \mathrm{C}$. As shown in Figure 3B, maximal erythroid maturation was reached within 3-4 days and remained constant thereafter. Strikingly, however, the total cell number decreased dramatically after 4 days, concomitant with the accumulation of disintegrated erythroid cells. This cell death could be partially prevented by the addition of anemic serum (data not shown). When chicken myelomonocytic growth factor (CMGF) was added instead, the total cell numbers continued to increase after $4-5$ days at $42^{\circ} \mathrm{C}$ although hemoglobin-positive cells still decreased sharply (Fig. 3B). These results indicate that after a prolonged shift of $t s 1.1$-transformed cells to the nonpermissive temperature, mature erythroid cells begin to disappear and a population of cells takes over whose growth is dependent on $\mathrm{CMGF}$.

\section{ts1.1-transformed progenitors exhibit elevated} levels of eosinophils

Because commitment along the eosinophil lineage can be induced in wild-type E26 MEPs (Graf et al. 1992), we 
A

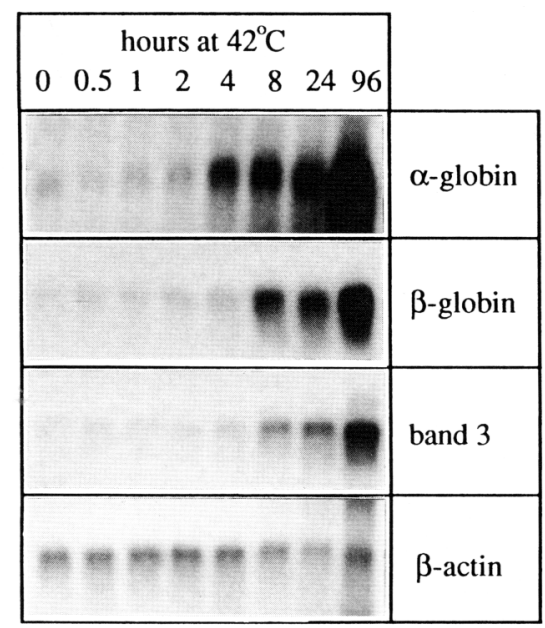

B

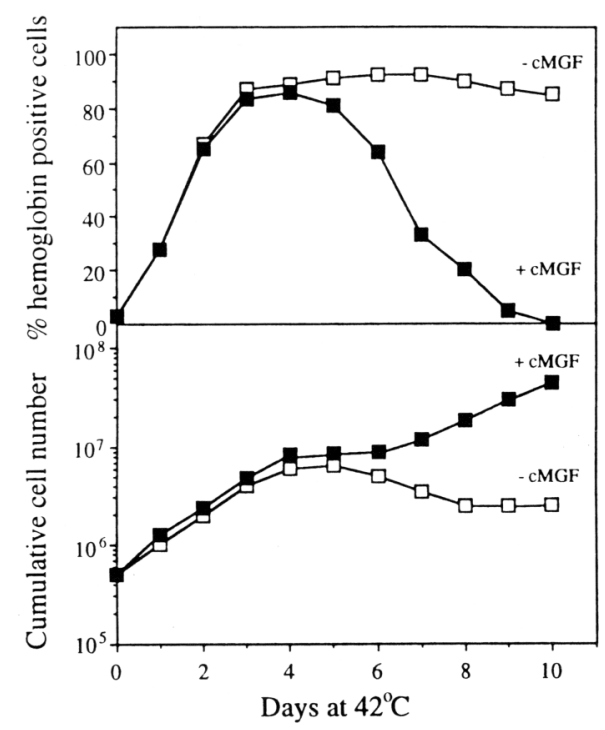

Figure 3. Temperature-induced erythroid differentiation of ts1.1-transformed cells. (A)ts1.1 E26-transformed cells (clone A6) were grown at $35^{\circ} \mathrm{C}$ or shifted to $42^{\circ} \mathrm{C}$ for the indicated times and analyzed by Northern blotting using the indicated probes. Blots were exposed for $2 \mathrm{hr}(\alpha$ - and $\beta$-globin) and $6 \mathrm{hr}$ (band 3 and $\beta$-actin). (B)ts 1.1 E26 cells (clone A3), shifted to $42^{\circ} \mathrm{C}$ for the indicated times in the presence $(\square)$ or absence $(\square)$ of cMGF. The percentage of hemoglobin-positive cells and cell numbers was determined at daily intervals.

tested $t s 1.1$-transformed progenitors grown either at $35^{\circ} \mathrm{C}$ or $42^{\circ} \mathrm{C}$ for the presence of peroxidase, the hallmark of avian eosinophils. As shown in Figure 4, most $t$ 1.1transformed erythroid colonies contained a significant number of granule-containing, peroxidase-positive cells already at $35^{\circ} \mathrm{C}$, with an average proportion of $3.3 \%$ (range $0-25 \%$ in 64 clones tested; Fig. 4A,B). This was surprising because none of the MEP colonies transformed by the wild-type virus contained $>1 \%$ peroxidase-positive cells (average of $\sim 0.01 \%$ in 36 colonies tested). Following shift of $t s 1.1$ clones to $42^{\circ} \mathrm{C}$ for 3 days
A

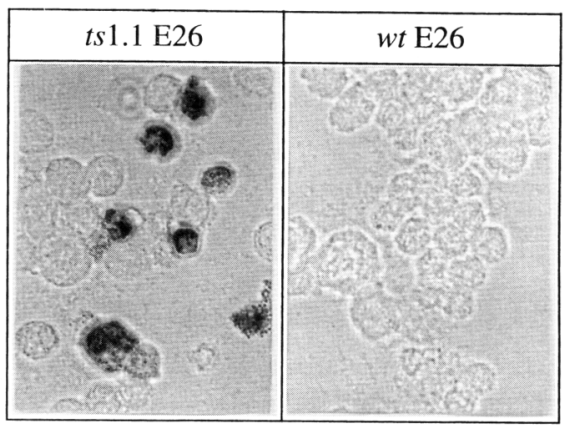

B

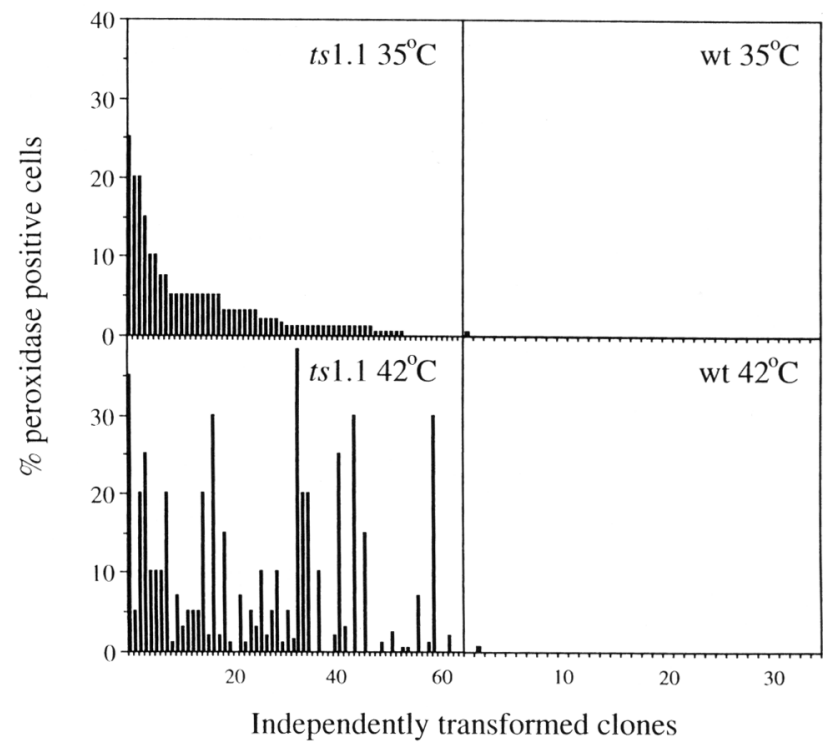

C

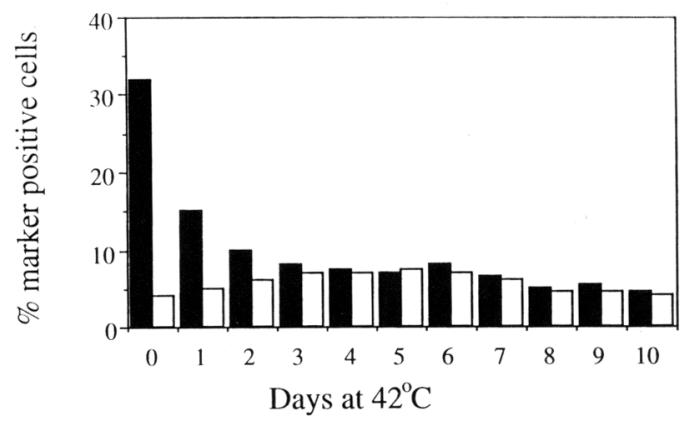

Figure 4. Presence of eosinophils in ts1.1 E26 transformed immature erythroid clones. (A) Pictures of a ts1.1 E26-transformed clone and of a wild-type E26-transformed MEP clone growing in tissue culture and stained with peroxidase reagent were taken under phase contrast. The dark cells contain peroxidase-positive granules. $(B)$ A total of 64 individual $t s 1.1$-transformed colonies and 36 individual wild-type E26-transformed MEP cells were expanded in the presence of $\mathrm{cMGF}$ at $35^{\circ} \mathrm{C}$ or shifted to $42^{\circ} \mathrm{C}$ for 3 days and stained with peroxidase reagent. The percentage of peroxidase-positive cells was scored, and colonies assayed at $35^{\circ} \mathrm{C}$ were plotted in decreasing order of expression (top boxes); the corresponding values at $42^{\circ} \mathrm{C}$ are shown in the bottom boxes. (C) ts 1.1 E26 cells (clone A6) were shifted to $42^{\circ} \mathrm{C}$ in the presence of $\mathrm{CMGF}$, and percentage of peroxidase positive cells (open bars) or EOS47 antigen-positive cells (solid bars) was determined. 
the average percentage of peroxidase-positive eosinophils was determined to be $7.6 \%$ (range $0-40 \%$ ). Of 64 clones analyzed, peroxidase staining increased twofold or more in $33 \%$, decreased twofold or more in $11 \%$, and was largely unaffected in the remaining $56 \%$. We then determined the kinetics of peroxidase and EOS47 surface antigen expression following shift to $42^{\circ} \mathrm{C}$ using an individual clone. EOS47 is an eosinophil-specific cell-surface antigen that corresponds to melanotransferrin /Graf et al. 1992, McNagny et al. 1992; K. McNagny and T. Graf, in prep.). As can be seen, the level of peroxidase-positive cells increased slightly following temperature shift while EOS47 antigen was down-regulated, closely corresponding to the proportion of peroxidase-positive cells.

These data show that ts1.1-transformed progenitors exhibit elevated levels of eosinophils compared with wild-type E26 and that these are temperature sensitive for maturation in a clone-dependent fashion. They also indicate that the bulk of nonerythroid cells observed after prolonged shifts of $t s 1.1$ cells to $42^{\circ} \mathrm{C}$ in the presence of cMGF cannot be explained by the presence of eosinophils.

\section{ts1.1-transformed progenitors can be induced to differentiate along the myelomonocytic lineage following shift to $42^{\circ} \mathrm{C}$}

Another possibility was that $t s 1.1$ progenitors can be induced to differentiate along the myelomonocytic in addition to the erythroid lineage. To investigate this we examined $t s 1.1$ cells shifted to $42^{\circ} \mathrm{C}$ in the presence of cMGF and monitored the morphology of cells from cytospins prepared at various intervals and stained with neutral benzidine and Giemsa. In parallel, samples were stained with acid benzidine /a sensitive indicator of hemoglobin) and with MYL51/2 antibodies, which detect a 200-kD cell-surface antigen specifically expressed on chicken myelomonocytic cells (Kornfeld et al. 1983; Golay et al. 1988; McNagny et al. 1992). As illustrated in Figure 5A, cells with the morphological characteristic of promyelocytes could be seen as early as 3-4 days after shift, essentially replacing mature erythroid cells by day 8. In addition, as shown in Figure 5, B and C, although MYL51/2 was not detectable on cells grown at $35^{\circ} \mathrm{C}$, it could be detected as early as 2 days after temperature shift, with $\sim 10 \%$ positive cells at day 4 and $95 \%$ after 10 days. The myelomonocytic cells contained granules that were Astra blue-staining positive but peroxidase negative (Golay et al. 1988; data not shown), they expressed the promyelocyte-specific mim-1 gene (Ness et al. 1989), and their growth required cMGF (data not shown). Of 98 ts1.1-transformed clones tested, 85 could be induced to express the MYL51/2 antigen at $42^{\circ} \mathrm{C}$, although all were inducible for erythroid differentiation.

In control experiments with wild-type E26-transformed MEP colonies incubated at $42^{\circ} \mathrm{C}$ for extended time periods, no detectable phenotypic changes or enhanced differentiation frequency along any of the three lineages could be observed (Fig. 3B; Golay et al. 1988; N. Kraut, J. Frampton, and T. Graf, unpubl.). From this we
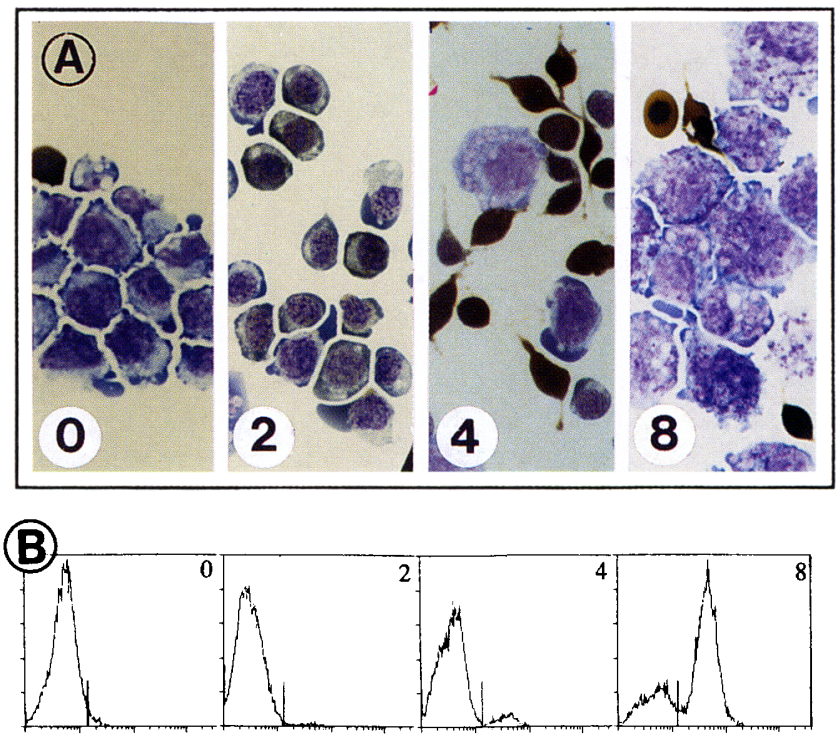

Relative fluorescence intensity

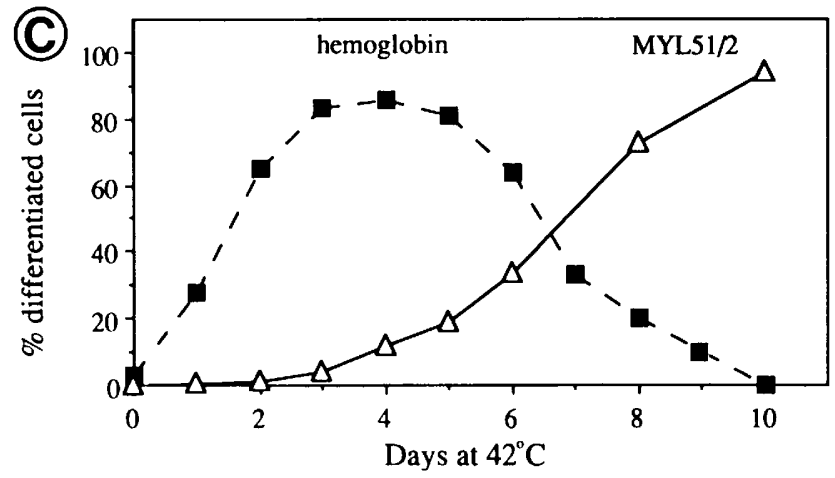

Figure 5. Temperature-induced generation of myelomonocytic cells from ts1.1-transformed progenitors. (A) ts 1.1 cells (clone E4) shifted in the presence of cMGF from $35^{\circ} \mathrm{C}$ to $42^{\circ} \mathrm{C}$ for the indicated time periods $(0,2,4$, and 8 days $)$ were subjected to cytocentrifugation, stained with benzidine at neutral $\mathrm{pH}$, counterstained with Diff-Quick, and photographed. Immature erythroid cells are stained blue/green, mature erythroid cells are stained brown, and promyelocytes are light blue. The latter cells are also larger and exhibit vacuoles and small purple granules. (B) FACS profiles of MYL51/2 expression in ts 1.1 cells shifted to $42^{\circ} \mathrm{C}$ for various times. The ordinate indicates the relative frequency of signal-positive cells. Cells were gated in such a way that all those to the left of the vertical bar were scored negative; all those to the right were positive. $(C)$ Percentages of MYL51/2 antigen and hemoglobin-positive cells deduced from FACS analysis $(\Delta)$ or benzidine staining $(\square)$.

conclude that the thermolability of Ets, rather than an unspecific temperature-induced process, is responsible for the induction of multilineage differentiation in $t s 1.1$ MEPs shifted to $42^{\circ} \mathrm{C}$.

In summary, our results show that the majority of the nonerythroid cells obtained after shifting tsl.1-transformed progenitors to $42^{\circ} \mathrm{C}$ correspond to promyelocytes. They also demonstrate that like wild-type E26 MEPs, tsl.1 erythroid cells have the option to differentiate along at least three different lineages. 
The onset of commitment to erythroid and myeloid differentiation is not separable

The relatively late appearance of myeloid cells expressing MYL51/2 antigen compared with erythroid cells expressing hemoglobin (Fig. 5) raised the possibility that a large part of the tsl.1 MEP population becomes committed to the erythroid lineage before the onset of myelomonocytic differentiation. If correct, short pulse shifts to $42^{\circ} \mathrm{C}$ should induce commitment only toward the erythroid lineage while more extended shifts should also induce commitment toward the myeloid lineage. To test this, three selected $t s 1.1$ MEP clones were shifted to $42^{\circ} \mathrm{C}$ for increasing lengths of time (Fig. $6 \mathrm{~A}$ ) in the presence and absence of cMGF. Following back-shift to $35^{\circ} \mathrm{C}$, they were then tested on day 6 for hemoglobin and MYL51/2 antigen expression. As can be seen from the averaged results plotted in Figure 6, B and C, 35-40\% of the cells became irreversibly induced to express hemoglobin after a pulse of 1 day under both conditions. In contrast, during the same time, $\sim 18 \%$ of the population was induced to express the myeloid marker MYL51/2. Interestingly, the induction of myeloid cells could only be observed in the presence, but not in the absence, of cMGF. These results suggest that temperature-induced commitment into erythroid and myeloid cells cannot be separated and show that most $t s 1.1$ MEPs become irreversibly committed within 2.5 days at the nonpermissive temperature.

\section{ts1.1-transformed multipotent progenitors are more} mature than those transformed by wild-type E26 virus

To further characterize the phenotype of tsl.1 MEPs they were stained with several monoclonal antibodies detecting cell-surface antigens of chick hematopoietic cells. The MEP21 antibody recognizes a $150-\mathrm{kD}$ antigen expressed on wild-type MEPs and on thrombocytes (McNagny et al. 1992); it is the marker that correlates best so far with the multilineage differentiation capacity of transformed hematopoietic cells. MEP26 recognizes a 47 to $60-\mathrm{kD}$ antigen expressed on wild-type MEPs, on certain erythroid precursors, and on normal thrombocytes (Metz and Graf 1991a; McNagny et al. 1992); BEN antibody recognizes a protein of the immunoglobulin superfamily that is expressed on committed hematopoietic cells of various lineages (Pourquie et al. 1992); JS4 recognizes an antigen expressed on late erythroid cells and on some neutrophil granulocytes (Schmidt et al. 1986); EOS47 recognizes chicken melanotransferrin, which is expressed on E26-transformed and on normal eosinophils (McNagny et al. 1992; K. McNagny and T. Graf, in prep.); MYL51/2 recognizes 170 - and $190-\mathrm{kD}$ proteins specifically expressed on normal and transformed myelomonocytic cells (Kornfeld et al. 1983; Graf et al. 1992); and LIBS6 recognizes the human-specific (Frelinger et al. 1991) and chicken thrombocyte-specific integrin GPIIb/IIIa (J. Frampton and T. Graf, unpubl.).

As illustrated in Figure 7, in comparison with wild-

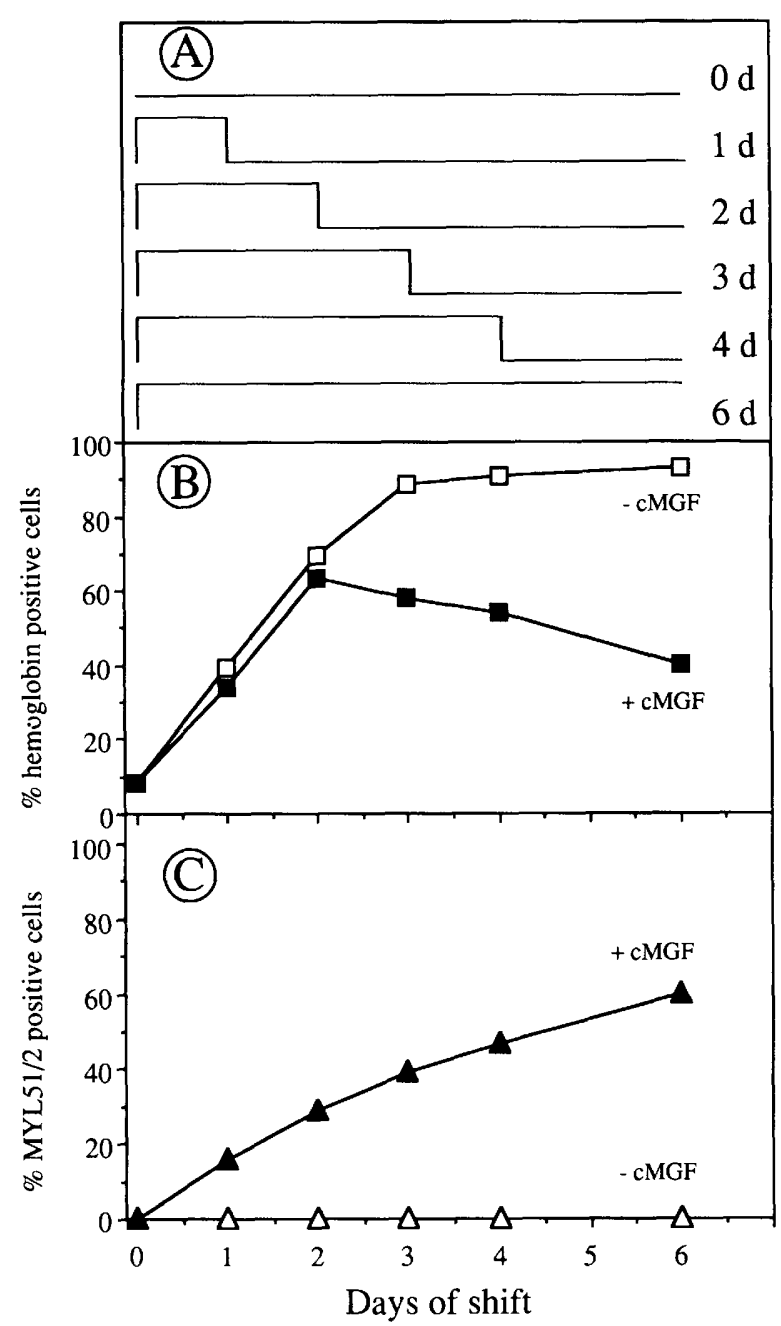

Figure 6. Pulse-shift analysis of temperature-induced lineage commitment. A pool of three tsl.1 MEP clones, selected for their inducibility to differentiate into promyelocytes, were subjected to the shift programs indicated in $A$ and analyzed for marker expression at day 6 . Values shown represent the average values obtained with the three clones. $(B)$ Cells were shifted in the presence ( $\square$ ) or absence ( $\square$ ) of CMGF and stained with benzidine to detect hemoglobin expression at day $6 .(C)$ Cells were shifted in the presence $(\Delta)$ or in the absence $(\triangle)$ of $\mathrm{cMGF}$ and analyzed for MYL51/2 expression at day 6 . Cell numbers obtained at day 6 were found to be similar in all shift protocols.

type MEPs, $t s 1.1$ MEPs showed decreased levels of MEP21 and MEP26 antigen but elevated levels of the JS4 and EOS47 antigens and slightly elevated levels of BEN antigen. Finally, like wild-type MEPs, tsl.1 MEPs were negative for the myeloid-specific antigen MYL51/2, the major histocompatibility complex (MHC) type II (Graf et al. 1992), and for the thrombocyte-specific GPIIb/IIIa antigen. Following shift to the nonpermissive temperature they showed a rapid down-regulation of MEP21 $150 \%$ within 1-2 days and $100 \%$ within 2-4 days) and a somewhat slower down-regulation of MEP26 antigen $150 \%$ within 2-3 days and $90 \%$ within 6 days) with no concomitant increase in GPIIb/IIIa expression (data not 


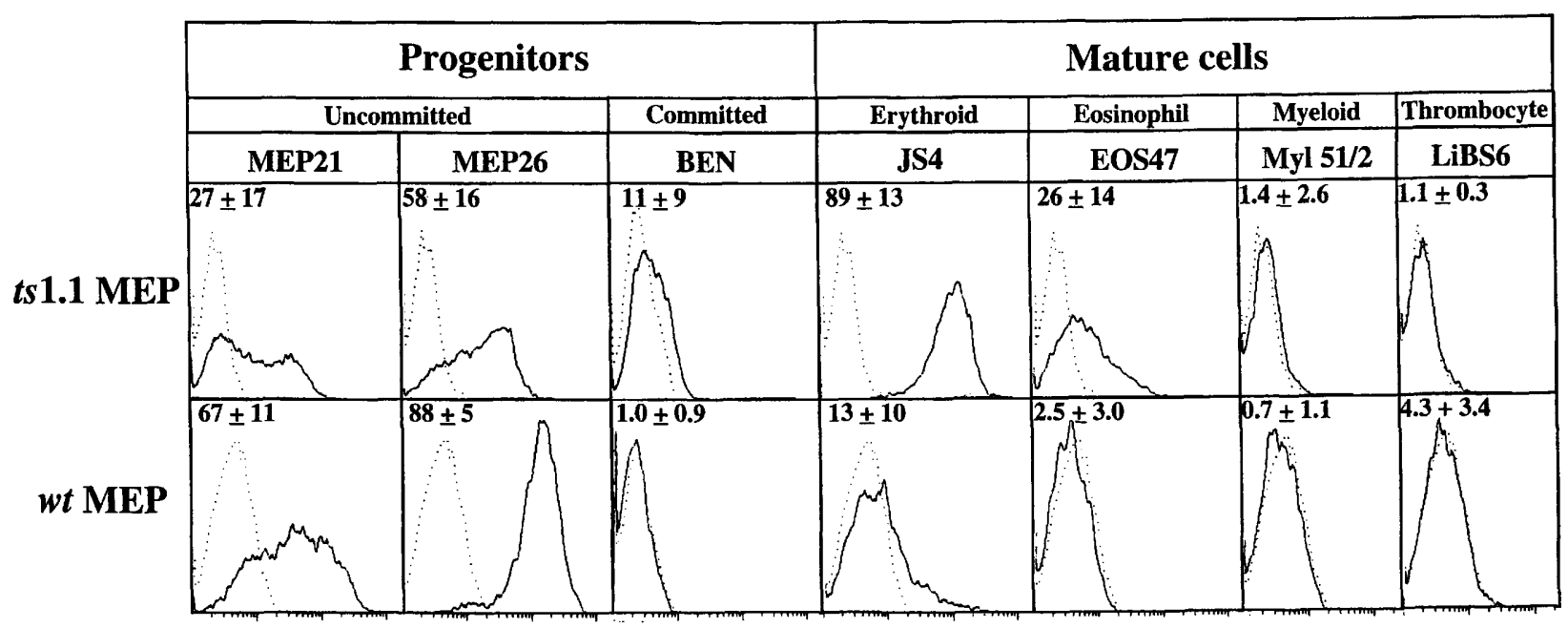

\section{Relative fluorescence intensity}

Figure 7. Cell-surface antigen expression of $t s 1.1$ and wild-type MEPs. The FACS profiles shown were obtained with one representative $t s 1.1$ and wild-type MEP clone each. The continuous lines represent the profiles obtained with the test antibody (top); the dotted lines, that of a control antibody. The values shown at the top left of each box represent the average percentage of positive cells with standard deviation. These values were obtained from 10 to 12 individually analyzed $t s 1.1$ MEP clones and from 4 to 7 wild-type MEP clones.

shown). No such effects could be seen with similarly shifted wild-type MEPs. These results, together with those described earlier in this paper, support the notion that multipotent progenitors transformed by $t s 1.1$ E26 virus express lineage-specific markers such as JS4 antigen (erythroid) and EOS47 antigen (eosinophilic).

To determine whether $t s 1.1$ MEPs, like wild-type E26 MEPs, can be induced to differentiate following treatment with the phorbol ester TPA, three randomly selected clones of each type were treated with $20 \mathrm{nM}$ TPA, $100 \mathrm{nM}$ TPA, or not at all. The cells were then scored after 10 days for the presence of erythroid, eosinophil, and myeloid cells. Both concentrations of TPA induced the outgrowth of myeloid cells (resembling promyelocytes) and, to a lesser extent, eosinophils. In contrast, wild-type MEPs were preferentially induced to differentiate into eosinophils with $20 \mathrm{nM}$ TPA and into myeloblasts with $100 \mathrm{nM}$ TPA, in accordance with published data (Graf et al. 1992).

\section{Discussion}

Influence of the ts1.1-Ets lesion on the DNAbinding capacity of the Myb-Ets oncoprotein

Our results have demonstrated a correlation between the DNA-binding capacity of the in vitro-synthesized ETS domain and the biological properties of the Myb-Ets oncoprotein. This strongly suggests that Myb-Ets blocks the differentiation of multipotent cells because of the interaction of the ETS domain with specific recognition sequences in the regulatory region of target genes. It has to be noted, however, that it has not yet been possible to demonstrate that the $t s 1.1$ fusion protein is also defective and thermosensitive for specific DNA binding of the ETS domain to DNA. This protein, when expressed in reticulocyte lysates, fails to recognize conventional Etsbinding sites and only does so when it is preincubated with excess Myb-binding sites (F. Lim, J. Frampton and T. Graf, unpubl.). Unfortunately, the low DNA-binding affinity of the $t s 1.1$ ETS domain has precluded Mybbinding site activation experiments. On the other hand, preliminary experiments with ts 1.1 Ets expressed together with v-erbA in an erbA-ets vector (Metz and Graf 1992) indicate that $t s 1.1$ Ets protein expressed in trans is thermolabile (N. Kraut and T. Graf, unpubl.).

The ETS domain, which contains $\sim 85$ amino acids, consists of a hydrophobic $5^{\prime}$ half and a $3^{\prime}$ half that is rich in basic amino acids. Histidine 1004, which is replaced by an aspartic acid in ts 1.1 (Leprince et al. 1983; Nunn et al. 1983; Golay et al. 1988), is located in the basic region next to a position that is occupied by a lysine in all 18 Ets family members reported to date. Although the histidine is less well conserved, its position is never occupied by an acidic amino acid, so that DNA binding may be reduced because of a repulsion with the negatively charged phosphates of the DNA backbone. Alternatively, the mutation may disturb the local conformation of the protein, for instance, by disrupting hydrophobic interactions that normally occur through the histidine ring. This alteration of the three-dimensional structure could be further disturbed at higher temperatures. The observed higher stability of the $t s 1.1 \mathrm{Myb}-\mathrm{Ets}$ protein compared with the wild-type protein would be in line with this interpretation. 
Phenotype of ts1.1-transformed progenitors and stages at which Myb-Ets blocks their differentiation

Our data show that $t s 1.1$-transformed progenitors are multipotent and that their commitment for differentiation along the erythroid, myeloid, and probably eosinophil lineages can be induced by temperature shift. However, there are considerable clonal variations, with $\sim 60 \%$ of all clones being tripotent /erythroid/eosinophil/myeloid), $20 \%$ being bipotent (erythroid/eosinophil or erythroid/myeloid), and another $20 \%$ corresponding to monopotent progenitors. A small-scale subcloning experiment supports this conclusion. Of 10 single cells derived from a ts 1.1-transformed colony $(3$ days after infection, consisting of $\sim 30$ cells), 3 subclones could be expanded in medium with anemic serum and cMGF. Two of these were found to be tripotent and one bipotent, being capable of differentiating along the erythroid and eosinophil lineages (T. Graf, unpubl.). We also found a considerable clonal variability of spontaneously differentiated erythroid, eosinophil, or myeloid cells observed at $35^{\circ} \mathrm{C}$, suggesting that even at the permissive temperature the differentiation block imposed by the fusion protein is not absolute, probably reflecting the reduced DNA-binding capacity of the Ets portion. The observed differences in the frequency of spontaneous and induced differentiation toward the various lineages suggests that the threshold activity of Ets required to block the commitment of myelomonocytic cells is lower than that required for the block of the erythroid lineage.

Although progenitors transformed by $t s 1.1$ at $35^{\circ} \mathrm{C}$ resemble wild-type MEPs in their multilineage differentiation capacity, they differ in a number of properties, summarized in Figure 8. First, their differentiation block is less tight, exhibiting an increased rate of spontaneous differentiation toward erythroid cells and eosinophils.
Second, they express cell-surface antigens characteristic of cells from various lineages. Third, $t s 1.1 \mathrm{MEPs}$ respond to, and at least partially require, anemic serum for survival and growth (data not shown), suggesting that they express the erythropoietin receptor. Whether their phenotype reflects that of a normal progenitor is not known. However, the cell morphology of at least some ts1.1transformed clones shifted to $42^{\circ} \mathrm{C}$ for $3-5$ days exhibits a remarkable similarity with smears from bone marrow cells of young chicks, suggesting that our model system reproduces a physiological process. The observation that most $t s 1.1$-transformed clones grown at $35^{\circ} \mathrm{C}$ appear to contain significant proportions of committed cells raises the possibility that the Myb-Ets fusion also blocks at the level of monopotent precursors. The observed rapid increase in erythroid-specific markers after shift to the nonpermissive temperature would be consistent with this possibility.

\section{Parallels between the biology of $\mathrm{v}$-Ets and Myb-Ets with that of other Ets family members}

Studies on the biology of E26 Myb-Ets do not allow a simple extrapolation to the function of c-Ets-1, but clues might be found by looking at some of the known functions of Ets proteins. It has been proposed that Ets family members serve as a relay station for the coordination of gene expression along signal transduction pathways in response to extracellular signals (Gutman and Wasylyk 1991; Langer et al. 1992; Macleod et al. 1992). For example, during serum/growth factor stimulation of fibroblasts, the Ets family members Elk-1 and SAP-1, together with serum response factor (SRF) mediate trans-activation of c-fos (Hipskind et al. 1991; Dalton and Treisman 1992). Similarly, in serum-stimulated or TPA-treated fi-

$$
w t \mathrm{E} 26
$$

ts $1.1 \mathrm{E} 263^{\circ} \mathrm{C}$

$t s 1.1 \mathrm{E} 2642^{\circ} \mathrm{C}$

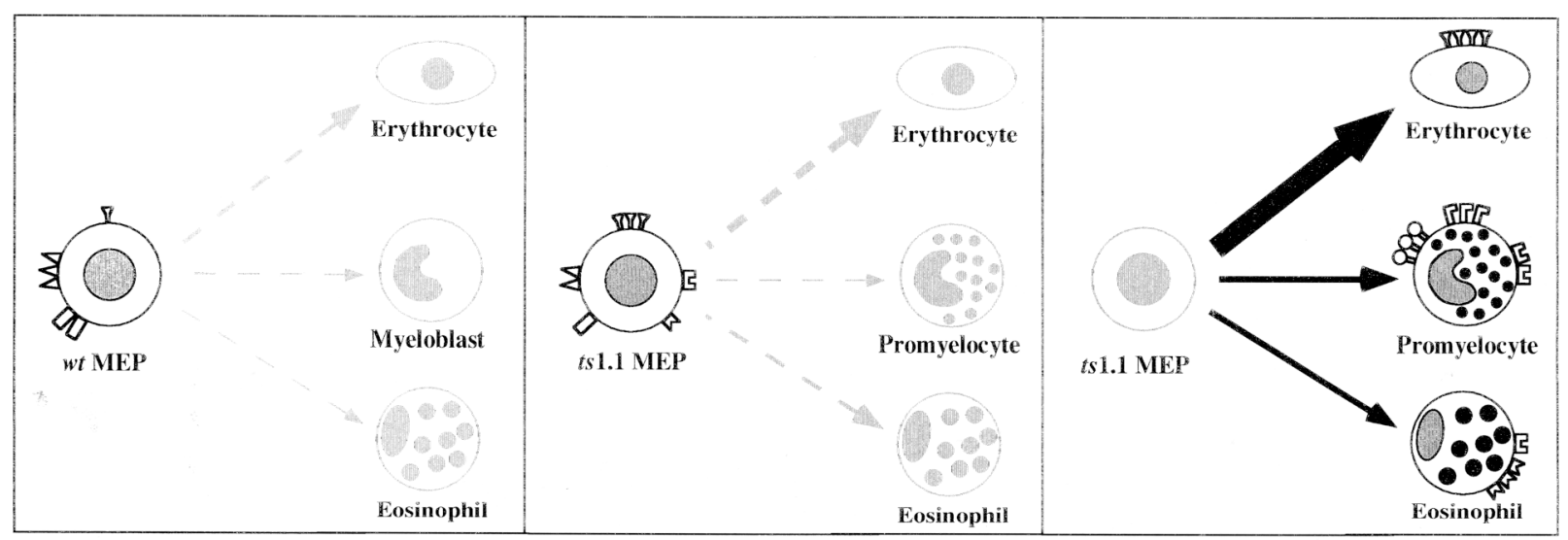

Figure 8. Scheme summarizing the phenotype of wild-type and tsl.1 MEPs and their differentiation capacities. The three boxes represent MEPs in which Ets is fully active [wild-type (wt) E26], partially active $\left(t s 1.1\right.$ at $\left.35^{\circ} \mathrm{C}\right)$, or inactive (ts 1.1 at $\left.42^{\circ} \mathrm{C}\right) .8$ roken arrows indicate spontaneous differentiation; solid arrows indicate induced differentiation, with the arrow strength indicating relative differentiation frequencies. Light gray printing of cells indicates that they represent minority populations; dark gray printing stands

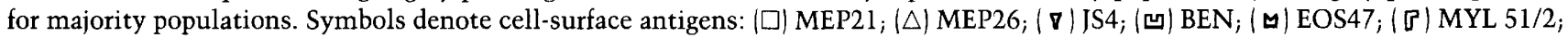
(8) MHC type II. One symbol indicates expression in $10-40 \%$ of the cells; two symbols indicate expression in $40-70 \%$ of the cells; three symbols indicate expression in $70-100 \%$ of the cells; four symbols indicate high levels of expression in $100 \%$ of the cells. 
broblasts, or following overexpression of ras or kinasetype oncogenes, Ets family proteins cooperate with AP-1 in transcriptional activation (Wasylyk et al. 1989, 1990). These properties may explain the capacity of $\mathrm{v}$-Ets to induce factor-independent proliferation of erythroid cells (Metz and Graf 1992) and the role of the ets-related fli-1 and spi-1 genes in the generation of murine erythroleukemias (Moreau-Gachelin et al. 1989; Ben-David et al. 1991). Moreover, Elk-1 has been shown to be phosphorylated by mitogen-activated protein (MAP) kinase (Marais et al. 1993), an enzyme that is at the bottom of the Ras signaling pathway (for review, see Crews and Erikson 1993). Because activation of the Ras pathway induces multilineage differentiation in wild-type MEPs (Graf et al. 1992) and in ts1.1 MEPs, it is possible that the DNA-binding capacity of the Ets domain is inactivated, as in $t s 1.1$ MEPs shifted to $42^{\circ} \mathrm{C}$. Finally, we point out the parallels with the results obtained with Myb-Ets and the properties of the Drosophila yan/pok gene. This ets family gene is required to maintain neuronal precursors in an undifferentiated state, acting antagonistically toward the sevenless/ras-induced neuronal differentiation pathway (Lai and Rubin 1992; Tei et al. 1992).

\section{A powerful system to identify target genes regulated by $M y b-E t s$ in multipotent hematopoietic progenitors}

Interestingly, in contrast to the role of Ets as revealed from our studies with tsl.1, Myb does not appear to be involved in blocking the differentiation commitment of MEPs along the erythroid, myeloid and eosinophil lineage, as suggested by experiments using a temperaturesensitive mutant of E26 with a lesion in the DNA-binding domain of Myb (Beug et al. 1984; J. Frampton and T. Graf, unpubl.). The mechanism by which the ETS domain of the E26 fusion protein inhibits lineage commitment could be based either on a repression of genes important for differentiation or on the induction of genes that enable multipotent progenitors to self-renew, or both. The observation that only Myb-Ets can transform multipotent progenitor cells while Myb and Ets expressed separately but in the same cell cannot (Metz and Graf 1991b; Graf et al. 1992) suggests that there are genes specifically regulated by the fusion protein, perhaps containing regulatory sequences with Myb- and Ets-binding sites in a characteristic arrangement. The ts1.1 E26 system provides a powerful tool to screen for genes that are rapidly activated or repressed through the Ets portion of the Myb-Ets protein. The identification of Myb-Ets-regulated genes may provide novel insights into the function of Ets family genes and, more generally, into leukemogenesis by fusion oncoproteins. Such target genes may shed new light on the regulation of growth and differentiation of multipotent hematopoietic progenitors.

\section{Material and methods}

\section{Blastoderm transformation assay and viruses}

Preparation, infection, and growth of blastoderm cultures in Methocel was as described earlier (Graf et al. 1992). Wild-type
E26 (Radke et al. 1982) and tsl.1 E26 (Golay et al. 1988) were used as RAV-2. The methylcellulose medium contained $2 \%$ anemic chicken serum as a source for erythropoietin (Radke et al. 1982), and 5-10 U/ml of crude cMGF (Leutz et al. 1984), in addition to blastoderm medium (Graf et al. 1992), which allows the outgrowth of both transformed myeloid and transformed erythroid cells. After 10 days of incubation at the respective temperatures $\left(35^{\circ} \mathrm{C}\right.$ for $t s 1.1$ virus; $37^{\circ} \mathrm{C}$ for wild-type virus), transformed colonies were isolated with a bent and drawn-out Pasteur pipette and grown in liquid blastoderm medium with or without $\mathrm{CMGF}$.

\section{Cytochemical methods}

Two techniques were used in the identification of hemoglobinpositive cells. In the first, the cells were subjected to cytocentrifugation, fixed with methanol, and stained with benzidine at neutral $\mathrm{pH}$ followed by a counterstaining with Giemsa (Diff Quick, Harleco), as described previously (Beug et al. 1982). In the second technique, cells were stained in the culture dishes with benzidine at acid $\mathrm{pH}$, according to Orkin et al. (1975); 200-300 cells were counted for each cell clone analyzed. The latter method detects late erythroid cells as well as more immature cells not detected by neutral benzidine.

Eosinophils were detected by staining with peroxidase reagent (Kaplow 1965; Graf et al. 1992). Peroxidase- and neutral benzidine-staining procedures were combined to detect both mature erythroid cells and mature eosinophils simultaneously. For the quantification of eosinophils, 200-300 cells were analyzed for each clone.

To identify promyelocytes, cells were subjected to cytocentrifugation and stained with Astra blue as described by Golay et al. (1988). Positive cells exhibited light blue granules.

\section{Cell-surface antigens}

Immunofluorescent staining of living cells was performed as described earlier (Radke et al. 1982). In brief, $\sim 1 \times 10^{6}$ cells were incubated with one of the following monoclonal antibodies: EOS47, MEP21 and MEP26 (McNagny et al. 1992); MYL51/2 (Kornfeld et al. 1983); BEN (Pourquie et al. 1992); IS4 (Schmidt et al. 1986); or LIBS6 (Frelinger et al. 1991). After washing, cells were incubated for $20 \mathrm{~min}$ at $4^{\circ} \mathrm{C}$ with fluorescein (FITC)-conjugated goat anti-mouse second antibody. Second antibody only was used as a negative control. Antigen-positive cells were evaluated under fluorescence illumination by counting 200-300 cells per sample or using the Becton Dickinson FACScan cytometer.

\section{Growth rate determination}

ts1.1 E26-transformed cells were washed twice and split into duplicate samples of $5 \times 10^{5}$ cells seeded in $2 \mathrm{ml}$ of blastoderm medium in the presence or absence of cMGF. The cells were then counted at daily intervals using a Coulter counter. A partial medium change was carried out every second day. Cells were diluted to $5 \times 10^{5}$ cells $/ \mathrm{ml}$ in fresh medium when their cell number exceeded $2 \times 10^{6}$ cells $/ \mathrm{ml}$. The cumulative cell number was calculated from the actual cell number and from the number of dilution steps.

\section{Pulse-shift experiments}

ts 1.1 E26 cells were kept in blastoderm medium with or without cMGF $(5-10 \mathrm{U} / \mathrm{ml})$ at $1 \times 10^{6}$ cells $/ 35-\mathrm{mm}$ dish, and partial 
medium changes were performed every 1-2 days. Cells were shifted to $42^{\circ} \mathrm{C}$ and kept for various time intervals before backshift to $35^{\circ} \mathrm{C}$. Evaluation was carried out at day 6 by staining with acid benzidine or MYL51/2 antibodies.

\section{Pulse-chase experiments}

ts1.1- and wild-type E26-transformed MEP clones were expanded to $4 \times 10^{7}$ cells, and half of them were shifted to $42^{\circ} \mathrm{C}$ for $24 \mathrm{hr}$. Shifted and control cells were pulse labeled with $\left[{ }^{35} \mathrm{~S}\right] \mathrm{me}$ thionine for $1 \mathrm{hr}$ and then rinsed once. An aliquot was lysed immediately, and the remaining cells were chased with a $1000 \times$ excess of cold methionine for the indicated times. Cell lysis was performed according to Ghysdael et al. (1986). Immunoprecipitation analyses were done on the same amount of acid-insoluble radioactive counts of each lysate using anti-Myb serum (Ness et al. 1987). Data were quantitated using the PhosphorImaging system (Molecular Dynamics).

\section{RNA preparation and Northern blot analyses}

Total RNA was isolated according to the single-step procedure described by Chomczynski and Sacchi (1987). Poly $(A)^{+}$RNA was isolated using oligo(dT)-cellulose (Sambrook et al. 1989). For Northern blots, $2 \mu \mathrm{g}$ of each sample was fractionated on a $1.2 \%$ agarose-formaldehyde gel and transferred to GeneScreen (DuPont) by capillary action (Sambrook et al. 1989). Blots were prehybridized at $42^{\circ} \mathrm{C}$ in $5 \times$ SSC, $50 \%$ deionized formamide, $5 \times$ Denhardt's solution, $0.1 \%$ SDS, and $0.1 \mathrm{mg} / \mathrm{ml}$ of salmon sperm DNA (Sigma) for at least $2 \mathrm{~h} \%$, and hybridized overnight in the same buffer containing DNA probes that were radiolabeled to high specific activity by random-primed synthesis (Feinberg and Vogelstein 1983). Probes employed for detection of mRNAs were specific for band 3 (Zenke et al. 1988), $\beta$-actin (Kost et al. 1983 ), adult chicken $\alpha$-globin and $\beta$-globin (globin probes were derived from cDNA clones obtained by differential screening for genes specifically expressed in ts1.1 E26-transformed cells at $42^{\circ} \mathrm{C}$; N. Kraut, unpubl.). Washing of hybridized filters was done twice in $2 \times$ SSC, $0.1 \%$ SDS, at room temperature and twice in $0.2 \times \mathrm{SSC}, 0.1 \% \mathrm{SDS}$, first at room temperature and then at $68^{\circ} \mathrm{C}$ for $1 \mathrm{hr}$. Blots were stripped to be reused for sequential hybridization experiments.

\section{Plasmids, probes, and DNA-binding assays}

Transcription templates were generated by PCR using the following plasmids and primers: c-etsKS template, T7N4, and T3 primers (Lim et al. 1992) to generate c-Ets ${ }^{\mathrm{N} \Delta 4}$ (amino acids 377 485 of c-Ets $1^{\mathrm{p} 68}$ ); v-etsKS template, T7N4, and PETSTOP primers (Lim et al. 1992) to generate v-Ets ${ }^{\mathrm{N} \Delta 4}$ (amino acids 377-488 of v-Ets); pvG. 3 vector containing ts 1.1 DNA (Golay et al. 1988), T7N4, and PETSTOP primers to generate $t s 1.1-\mathrm{Ets}^{\mathrm{N} \Delta 4}$ (amino acids 377-488 of ts 1.1-v-Ets).

In vitro transcription using PCR products and in vitro translation reactions $(50 \mu \mathrm{l})$ using $1-2 \mu \mathrm{g}$ of RNA were performed according to Lim et al. (1992). For gel mobility retardation assays, proteins $(1-5 \mu$ l of translation reaction) were incubated with binding buffer, which contained $100 \mathrm{mM} \mathrm{KCl}, 20 \%$ glycerol, $20 \mathrm{~mm}$ Tris- $\mathrm{HCl}$ (pH 6.8), $0.2 \mathrm{~mm}$ EDTA, $1 \mathrm{mM}$ DTT, and $1 \mu \mathrm{g}$ of poly[d(I-C)]. Approximately $1 \mathrm{ng}$ of $\left[{ }^{32} \mathrm{P}\right] \mathrm{dCTP}$-labeled PEA3 probe (Lim et al. 1992) with a sp. act. of $1 \times 10^{8}$ to $5 \times 10^{8}$ $\mathrm{cpm} / \mu \mathrm{g}$ (fill-in reaction performed with Klenow fragment) was added to the reaction, and the mix was incubated either at room temperature or at $42^{\circ} \mathrm{C}$ for $20 \mathrm{~min}$. The titration experiment shown in Figure 1B was performed by incubating the in vitrosynthesized proteins with increasing amounts $(0.5-1000 \mathrm{ng})$ of
PEA3 oligonucleotide. The specific radioactivity of the oligonucleotide probe was adjusted at each concentration tested to achieve the same quantities of radiolabel in the bound fraction. In the experiments described in Figure $2 \mathrm{~B}$, samples were first incubated at $42^{\circ} \mathrm{C}$ for $20 \mathrm{~min}$ and then back-shifted to room temperature. The reaction mixtures were then loaded onto a $6 \%$ nondenaturing polyacrylamide gel containing $2.5 \%$ glycerol in $25 \mathrm{~mm}$ Tris base/190 mM glycine buffer. Electrophoresis was carried out at $22^{\circ} \mathrm{C}$. After electrophoresis, the gel was dried and exposed for autoradiography. Bands corresponding to proteinbound oligonucleotide and free double-stranded oligonucleotide were cut out and placed in scintillant, and the radioactivity was determined.

\section{Acknowledgments}

We are grateful to F. Lim for advice on DNA-binding assays; D. Bohmann, A. Ephrussi, P. Kahn, and M. Mlodzik for help with the manuscript; H. Kulessa, A. Leutz, F. Lim, F. Rossi, and all other members of the Graf laboratory for discussions; S. Grieser-Ade and G. Döderlein for technical assistance; G. Smith for help with FACS analyses; M. Ginsberg for providing the LIBS6 antibody; and I. Fraignaud and H. Davies-Rück for typing the manuscript. This work was supported in part by a grant to the Sonderforschungsbereich 229 by the Deutsche Forschungsgemeinschaft. K. M. was supported by a fellowship from the Human Frontier Science Program.

The publication costs of this article were defrayed in part by payment of page charges. This article must therefore be hereby marked "advertisement" in accordance with 18 USC section 1734 solely to indicate this fact.

\section{References}

Ben-David, Y., E.B. Giddens, K. Letwin, and A. Bernstein. 1991. Erythroleukemia induction by Friend murine leukemia virus: Insertional activation of a new member of the ets gene family, Fli-1, closely linked to c-ets-1. Genes \& Dev. 5: 908918.

Beug, H., S. Palmieri, C. Freudenstein, H. Zentgraf, and T. Graf. 1982. Hormone-dependent terminal differentiation in vitro of chicken erythroleukemia cells transformed by ts mutants of avian erythroblastosis virus. Cell 28: 907-919.

Beug, H., A. Leutz, P. Kahn, and T. Graf. 1984. Ts mutants of E26 leukemia virus allow transformed myeloblasts, but not erythroblasts or fibroblasts, to differentiate at the nonpermissive temperature. Cell 39: 579-588.

Chomczynski, P. and N. Sacchi. 1987. Single-step method of RNA isolation by acid guanidinium thiocyanate-phenolchloroform extraction. Anal. Biochem. 162: 156-159.

Crews, C.M. and R.L. Erikson. 1993. Extracellular signals and reversible protein phosphorylation: What to Mek of it all. Cell 74: 215-217.

Dalton, S. and R. Treisman. 1992. Characterization of SAP-1, a protein recruited by serum response factor to the c-fos serum response element. Cell 68: 597-612.

Feinberg, A.J. and B. Vogelstein. 1983. A technique for radiolabelling DNA restriction endonuclease fragments to high specific activity. Anal. Biochem. 132: 6-13.

Frelinger, A.L. III., X. Du, E.F. Plow, and M.H. Ginsberg. 1991. Monoclonal antibodies to ligand-occupied conformers of integrin $\alpha I I b \beta 3$ (GPIIb-IIIa) alter receptor affinity, specificity, and function. J. Biol. Chem. 266: 17106-17111.

Ghysdael, J., P. Gegonne, P. Pognonec, D. Leprince, and D. Stehelin. 1986. Identification and preferential expression in thy- 
mic and bursal lymphocytes of a c-ets oncogene-encoded $M_{r}$ 54,000 cytoplasmic protein. Proc. Natl. Acad. Sci. 83: 1714 1718.

Golay, J., M. Introna, and T. Graf. 1988. A single point mutation in the v-ets oncogene affects both erythroid and myelomonocytic cell differentiation. Cell 55: 1147-1158.

Graf, T. 1992. Myb: A transcriptional activator linking proliferation and differentiation in hematopoietic cells. Curr. Opin. Genet. Dev. 2: 249-255.

Graf, T., K. McNagny, G. Brady, and J. Frampton. 1992. Chicken "erythroid" cells transformed by the Gag-Myb-Ets encoding E26 leukemia virus are multipotent. Cell 70: 201-213.

Greenberger, J.S., N. Hoffman, M. Lieberman, L.E. Botnick, M.A. Sakakeeny, and R.J. Eckner. 1983. Pool size of pluripotent hematopoietic stem cells increased in continous bone marrow culture by Friend spleen focus forming virus. J. Natl. Cancer Inst. 70: 323-331.

Gutman, A. and B. Wasylyk. 1991. Nuclear targets for transcription regulation by oncogenes. Trends Genet. 7: 49-54.

Hipskind, R.A., V.N. Rao, C.G.F. Müller, E.S.P. Reddy, and A. Nordheim. 1991. Ets-related protein Elk-1 is homologous to the c-fos regulatory factor $\mathrm{p} 62^{\mathrm{TCF}}$. Nature 354: 531-534.

Introna, M., J. Golay, J. Frampton, T. Nakano, S.A. Ness, and T. Graf. 1990. Mutations in $v-m y b$ alter the differentiation of myelomonocytic cells transformed by the oncogene. Cell 63: 1287-1297.

Kaplow, L.S. 1965. Simplified myeloperoxidase stain using benzidine hydrochloride. Blood 26: 215-219.

Karim, F.D., L.D. Urness, C.S. Thummel, M.J. Klemz, S.R. McKercher, A. Celada, C. Van Beveren, R.A. Maki, C.V. Gunther, J.A. Nye, and B.J. Graves. 1990. The ETS-domain: A new DNA-binding motif that recognizes a purine-rich core DNA sequence. Genes \& Dev. 4: 1451-1453.

Knight, J., M. Zenke, C. Disela, E. Kowenz, P. Vogt, J.D. Engel, M.J. Hayman, and H. Beug. 1988. Temperature-sensitive v-sea transformed erythroblasts: A model system to study gene expression during erythroid differentiation. Genes \& Dev. 2: 247-258.

Kornfeld, S., H. Beug, G. Döderlein, and T. Graf. 1983. Detection of avian hematopoietic cell surface antigens with monoclonal antibodies to myeloid cells: Their distribution on nor$\mathrm{mal}$ and leukemic cells of various lineages. Exp. Cell Res. 143: 383-394.

Kost, T.A., N. Theodorakis, and S.H. Hughes. 1983. The nucleotide sequence of the chick cytoplasmic $\beta$-actin gene. $\mathrm{Nu}$ cleic Acids Res. 11: 8287-8301.

Lai, Z.-C. and G.M. Rubin. 1992. Negative control of photoreceptor development in Drosophila by the product of the yan gene, an ETS domain protein. Cell 70: 609-620.

Langer, S.J., D.M. Bortner, M.F. Roussel, C.J. Sherr, and M.C. Ostrowski. 1992. Mitogenic signaling by colony-stimulating factor 1 and ras is suppressed by the ets-2 DNA-binding domain and restored by myc overexpression. Mol. Cell. Biol. 12: 5355-5362.

Leprince, D., A. Gegonne, J. Coll, C. de Taisne, A. Schneeberger, C. Lagrou, and D. Stehelin. 1983. A putative second cellderived oncogene of the avian leukemia retrovirus E26. $\mathrm{Na}$ ture 306: 395-397.

Leutz, A., H. Beug, and T. Graf. 1984. Purification and characterization of $\mathrm{CMGF}$, a novel chicken myelomonocytic growth factor. EMBO I. 3: 3191-3197.

Lim, F., N. Kraut, J. Frampton, and T. Graf. 1992. DNA binding by c-Ets-1, but not v-Ets, is repressed by an intramolecular mechanism. EMBO J. 11: 643-652.

Lüscher, B., and R.N. Eisenman. 1990. New light on Myc and Myb. Part II. Myb. Genes \& Dev. 4: 2235-2241.
Macleod, K., D. Leprince, and D. Stehelin. 1992. The ets gene family. Trends Biochem. Sci. 17: 251-256.

Marais, R., J. Wynne, and R. Treisman. 1993. The SRF accessory protein Elk-1 contains a growth factor-regulated transcriptional activation domain. Cell 73: 381-393.

McNagny, K. M., F. Lim, S. Grieser, and T. Graf. 1992. Cell surface proteins of chicken hematopoietic progenitors, thrombocytes and eosinophils detected by novel monoclonal antibodies. Leukemia 6: 975-984.

Metcalf, D. 1989. The molecular control of cell division, differentiation commitment and maturation in haemopoietic cells. Nature 339: 27-30.

Metz, T. and T. Graf. 1991a. v-myb and v-ets transform chicken erythroid cells and cooperate both in trans and in cis to induce distinct differentiation phenotypes. Genes \& Dev. 5: 369-380.

- 1991b. Fusion of the nuclear oncoproteins $\mathrm{v}-\mathrm{Myb}$ and v-Ets is required for the leukemogenicity of E26 virus. Cell 66: 95-105.

1992. The nuclear oncogenes v-erbA and v-ets cooperate in the induction of avian erythroleukemia. Oncogene 7: 597-605.

Moreau-Gachelin, F., D. Ray, M.-G. Mattei, P. Tambourin, and A. Tavitian. 1989. The putative oncogene spi-1: Murine chromosomal translocation and transcriptional activation in murine acute erythroleukemias. Oncogene 4: 1440-1456.

Moscovici, M.G., P. Jurdic, J. Samarut, L. Gazzolo, C.V. Mura, and C. Moscovici. 1983. Characterization of the hemopoietic target cells for the avian leukemia virus E26. Virology 129: 65-78.

Ness, S.A., H. Beug, and T. Graf. 1987. V-myb dominance over $\mathrm{v}-\mathrm{myc}$ in doubly transformed chick myelomonocytic cells. Cell 51: 41-50.

Ness, S.A., A. Marknell, and T. Graf. 1989. The v-myb oncogene product binds to and activates the promyelocyte-specific mim-1 gene. Cell 59: 1115-1125.

Nunn, M., P.H. Seeburg, C. Moscovici, and P.H. Duesberg. 1983. Tripartite structure of the avian erythroblastosis virus E26 transforming gene. Nature 306: 391-395.

Orkin, S.H., F.I. Harosi, and P. Leder. 1975. Differentiation in erythroleukemic cells and their somatic hybrids. Proc. Natl. Acad. Sci. 72: 98-102.

Pourquie, O., C. Corbel, J.P. Le Caer, J. Rossier, and N.M. Le Douarin. 1992. BEN, a surface glycoprotein of the Ig superfamily, is expressed on a variety of developing systems. Proc. Natl. Acad. Sci. 89: 5261-5265.

Radke, K., H. Beug, S. Kornfeld, and T. Graf. 1982. Transformation of both erythroid and myeloid cells by E26, an avian leukemia virus that contains the myb gene. Cell 31: 643653.

Sambrook, J., E.F. Fritsch, and T. Maniatis. 1989. Molecular cloning: A laboratory manual, 2nd ed. Cold Spring Harbor Laboratory, Cold Spring Harbor, New York.

Schmidt, J.A., J. Marshall, M.J. Hayman, G. Döderlein, and H. Beug. 1986. Monoclonal antibodies to novel erythroid differentiation antigens reveal specific effects of oncogenes on the leukaemic cell phenotype. Leuk. Res. 10: 257-272.

Sotirov, N. 1981. Histone H5 in the immature blood cells of chickens with leukosis induced by avian leukemia virus strain E26. I. Natl. Cancer Inst. 66: 1143-1149.

Spooncer, E., D. Boettiger, and T.M. Dexter. 1984. Continous in vitro generation of multipotential stem cell clones from srcinfected cultures. Nature 310: 228-230.

Tei, H., I. Nihonmatsu, T. Yokokura, R. Ueda, Y. Sano, T. Okuda, K. Sato, K. Hirata, S.C. Fujita, and D. Yamamoto. 1992. pokkuri, a Drosophila gene encoding an E-26-specific 
(Ets) domain protein, prevents overproduction of the R7 photoreceptor. Proc. Natl. Acad. Sci. 89: 6856-6860.

Wasylyk, C., P. Flores, A. Gutman, and B. Wasylyk. 1989. PEA3 is a nuclear target for transcription activation by non-nuclear oncogenes. EMBO I. 8: 3371-3378.

Wasylyk, B., C. Wasylyk, P. Flores, A. Begue, D. Leprince, and D. Stehelin. 1990. The c-ets proto-oncogenes are transcription factors that cooperate with c-fos and c-jun for transcriptional activation. Nature 346: 191-193.

Zenke, M., P. Kahn, C. Disela, B. Vennstroem, A. Leutz, K. Keegan, M.J. Hayman, H.-R. Choi, N. Yew, J.D. Engel, and H. Beug. 1988. v-erbA specifically suppresses transcription of the avian erythrocyte anion transporter (band 3) gene. Cell 52: $107-119$. 


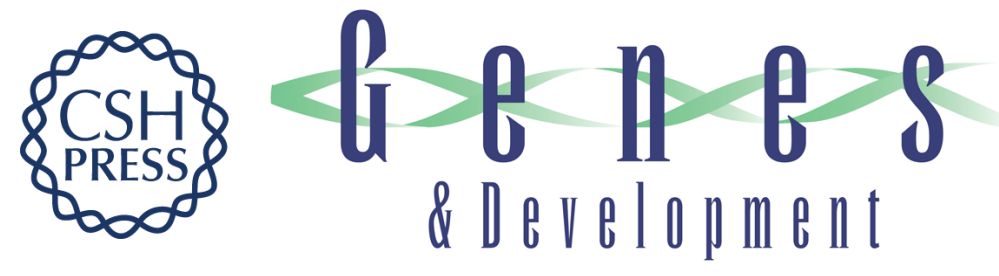

\section{A functional Ets DNA-binding domain is required to maintain multipotency of hematopoietic progenitors transformed by Myb-Ets.}

N Kraut, J Frampton, K M McNagny, et al.

Genes Dev. 1994, 8:

Access the most recent version at doi:10.1101/gad.8.1.33

References This article cites 49 articles, 11 of which can be accessed free at:

http://genesdev.cshlp.org/content/8/1/33.full.html\#ref-list-1

License

Email Alerting

Service

Receive free email alerts when new articles cite this article - sign up in the box at the top right corner of the article or click here.

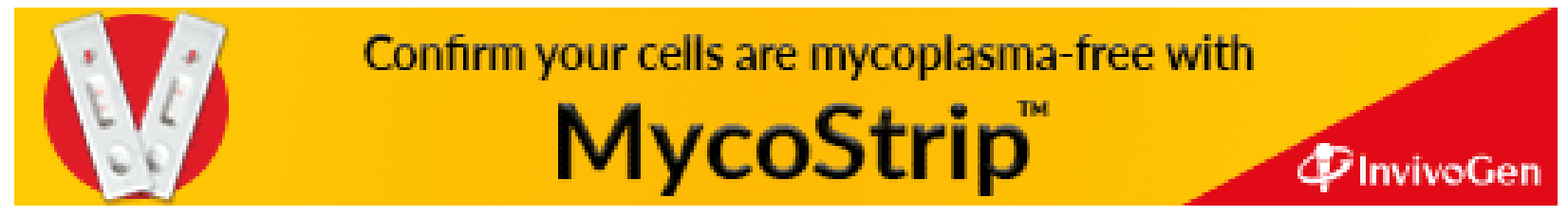

